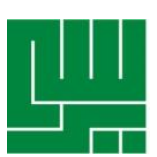

\title{
Gambaran Kepuasan Pernikahan Pada Penyintas Kanker Serviks Pasca Pengobatan Kanker
}

\section{Description Of Marriage Satisfaction On The Cervical Cancer Survivors After Cancer Treatment}

\author{
Evryanti Cahaya Putri ${ }^{1}$ dan Venie Viktoria Rondang Maulina ${ }^{2}$ \\ Fakultas Psikologi, Unika Atma Jaya \\ Jln. Jendral Sudirman kav. 5112930 Jakarta Pusat \\ Email: evryantiputri@yahoo.com; venie.viktoria@atmajaya.ac.id
}

\begin{abstract}
KATA KUNCI kepuasan pernikahan, penyintas kanker serviks, pasca pengobatan kanker

KEYWORDS marital satisfaction, cervical cancer survivor, post-cancer treatment
\end{abstract}

ABSTRAK

ABSTRACT After treatment, cervical cancer survivors experience changes in physical, psychological, social support, changes in intimacy and sexuality, family economy, as well as loyalty and trust issues with 
spouse. Those things are related to the characteristics that affect a person's marital satisfaction. Marital satisfaction can make a couple maintain a marriage or end their marriage and for the cancer survivors significantly related to their quality of life. This study used a qualitative approach with a semi-structured interview method. There are two subjects with characteristic: cervical cancer survivors who have completed treatment of cancer, married, and lives with their husband. The results of this study concluded that both participant marriage life after cancer treatment is perceived satisfied. Characteristics that support both participants' marital satisfaction is companionship, commitment, responsibility, unselfishness, honesty, trust, and fidelity, as well as the adaptability, flexibility, and tolerance. Characteristics that do not support are admiration and respect, spirituality and values, and affection. Different characteristics that influenced marital satisfaction from both participants are communication, ability to deal with crises and stress, as well as empathy and sensitivity. Factors that affect marital satisfaction for both participants is the closeness before marriage, home, and family income. Factors that have a different effect is the happiness of parents' marriage and education. Husband had a great influence for cervical cancer survivor in perceiving marital satisfaction.

\section{PENDAHULUAN}

Kanker serviks merupakan salah satu gangguan pada sistem reproduksi perempuan dan merupakan tumor ganas kedua paling tinggi angka kejadiannya di dunia (Castilaw \& Wittet, dalam Erfina, Afiyanti, \& Rachmawati, 2010). Kanker serviks merupakan salah satu jenis kanker yang mengalami pertumbuhan sel-sel abnormal pada jaringan leher rahim. Sel-sel abnormal tersebut terbentuk oleh sel-sel jaringan yang tumbuh terus menerus dan tidak terbatas pada bagian leher rahim. Tingkat keganasan pada kanker serviks cukup tinggi dan menjadi penyebab kematian utama akibat kanker pada wanita di negara-negara berkembang (Fitriana \& Ambarini, 2012). Kanker serviks seringkali ditemukan saat stadium lanjut karena gejala-gejala dini kanker serviks sulit dideteksi. Hal ini menyebabkan kematian dalam waktu yang cepat pada penderitanya. Angka ketahanan hidup dalam dua tahun untuk stadium lanjut berkisar $53,2 \%$ dan stadium awal hampir 90\% (Diananda, 2008).

Seseorang yang didiagnosis kanker dan masih berjuang untuk mempertahankan hidupnya disebut sebagai survivors atau penyintas. Menurut Bloom (dalam Baider, Cooper, \& De-Nour, 2000) terdapat tiga tahapan setelah seseorang didiagnosis kanker yaitu acute stage of survival, extended stage of survival, dan permanent survival. Penyintas pada acute stage of survival adalah ketika seseorang mulai didiagnosis, memilih jenis treatment, dan rencana treatment tersebut dilaksanakan. Extended stage of survival dimulai sejak treatment aktif berakhir. Permanent survival dimulai ketika perhatian individu akan kembalinya penyakit yang pernah dialami mulai menghilang (Bloom dalam Baider, Cooper, \& De-Nour, 2000)

Penyintas kanker serviks identik dengan konsep feminimitas yang 
berhubungan dengan hal-hal terkait perempuan. Perempuan yang didiagnosis kanker serviks mengalami kegalauan tentang identitasnya sebagai perempuan yang tidak sempurna karena rahimnya tidak berfungsi normal, serta dampaknya setelah 'kewanitaannya' telah tiada (Nurrachman, N., et al., 2011). Kondisi ini akan membawa perempuan pada persoalan yang lain dalam rumahtangga. Dia berisiko mengalami kesulitan berhubungan seksual dengan suaminya, selain itu tentu saja ia tidak lagi mampu hamil dan melahirkan (Nurrachman, N., et al., 2011).

Pengobatan atau treatment yang dapat dilakukan penyintas untuk mengatasi kanker serviks dapat berupa histerektomi, kemoterapi, dan radioterapi. Histerektomi merupakan operasi pengangkatan bagian uterus. Kemoterapi merupakan terapi sistemik yang dapat digunakan untuk menghambat pertumbuhan atau membunuh sel-sel kanker dengan obatobat anti kanker yang disebut sitostatika. Radioterapi adalah pengobatan yang dilakukan dengan menggunakan sinar radiasi (Sukardja, 2000).

Setiap pengobatan memberikan dampak fisik tersendiri bagi para penyintas kanker serviks. Pengobatan berupa histerektomi dapat menyebabkan perempuan kehilangan fungsi menstruasi, infertilitas, dan disfungsi seksual. Pengobatan berupa pembedahan dapat menyebabkan penurunan hormon estrogen. Penurunan hormon tersebut dapat menyebabkan sindrom postmenopause serta meningkatkan risiko terjadinya osteoporosis dan penyakit kardiovaskuler (Keyser \& Scot, 2007). Pengobatan dalam bentuk radioterapi dapat menyebabkan kekeringan pada vagina dan oklusi. Hal tersebut dapat menyebabkan infertilitas (Keyser \& Scot, 2007).

Para penyintas kanker serviks tidak hanya dihadapkan pada perubahan secara fisik, tetapi juga dampak psikologis. Dampak psikologis yang terjadi akibat dari terapi kanker berupa gangguan kepuasan seksual, gangguan intimacy dengan pasangan, memiliki rasa kurang percaya diri, gangguan akan gambaran diri, dan berkurangnya rasa feminimitas sebagai perempuan (Schultz \& Van De Wiel; Brotto; Wilmoth, dalam Afiyanti, Azwar, Setyowati, \& Andrijono, 2014). Para wanita penyintas kanker biasanya akan menarik diri, merasa malu, dan bergantung dengan orang di sekitarnya, sehingga hal tersebut akan memengaruhi kualitas hidup mereka (Keyser \& Scot, 2007). Evelyn (2005) mengungkapkan bahwa penyintas kanker serviks, khususnya yang telah menjalani pengobatan seperti kemoterapi, radiasi, dan pembedahan akan memiliki risiko untuk mengalami masalah seksualitas. Selain itu, menopause dini yang terjadi membuat penyintas mengalami penurunan hormon yang menyebabkan secara psikologis kurang bergairah untuk melakukan hubungan seksual. Penyintas kanker serviks merasa takut ketika suaminya mulai mendekatinya dan mengajak berhubungan seksual dan juga merasa sakit pada vaginanya. Hal tersebut disebabkan oleh perubahan organ seksual akibat dari terapi kanker yang dijalaninya (Gamel, Hengeveld, \& Davis, 2000).

Penyintas kanker membutuhkan dukungan dan perhatian dari keluarga dari awal didiagnosis hingga pengobatan berakhir atau pada masa pemulihan. Pada kenyataannya, penyintas tidak selalu mendapatkan dukungan dan perhatian seperti yang mereka harapkan dan butuhkan 
(Hidayat, 2005). Setelah penyintas selesai menjalani pengobatan, keluarga biasanya mengharapkan penyintas untuk kembali pada peran dan aktivitasnya seperti sebelum mereka didiagnosis kanker. Hal tersebut diikuti dengan tindakan mulai mengurangi dan menarik dukungan yang biasa diberikan selama masa pengobatan (Hewitt, 2004). Adanya sikap keluarga semacam ini membuat penyintas merasa dukungan sosial yang masih ia perlukan kurang didapatkan lagi dari keluarganya (Bloom, dalam Hidayat, 2005). Penyintas masih merasakan dampak dari pengobatan dan masih merasa takut akan kembalinya penyakit yang pernah mereka alami.

Penyintas kanker serviks juga merasakan permasalahan dengan pasangannya terkait dengan kepercayaan dan kesetiaan. Effendi (2011) menyatakan bahwa istri yang mengidap kanker akan merasa curiga bahwa suaminya akan "bermain di luar", selingkuh, dan menikah lagi. Kepercayaan dan kesetiaan kepada pasangan tersebut terkait dengan hubungan pernikahan pasangan. Menurut DeGenova (2008), sebuah kejujuran, kesetiaan, dan kepercayaan merupakan hal yang dapat mengikat sebuah hubungan dan terkait dengan kepuasan pernikahan pasangan.

Para penyintas kanker serviks tidak hanya dihadapkan pada persoalan dukungan sosial, kepercayaan, dan kesetiaan, tetapi juga permasalahan lain seperti situasi sulit terkait keadaan ekonomi keluarga. Setelah menjalani pengobatan, keadaan ekonomi keluarga memungkinkan untuk berubah karena pengobatan kanker memerlukan biaya yang besar. Para penyintas kanker sangat mengkhawatirkan sakitnya, ditambah dengan mengeluarkan biaya yang besar, sehingga sering muncul kecemasan antara memikirkan sakit atau biaya yang harus dikeluarkan (Yolanda \& Karwur, 2013). Pendapatan keluarga merupakan faktor yang memengaruhi kepuasan pernikahan karena pemasukan yang dapat memenuhi kebutuhan pokok keluarga akan meminimalisir timbulnya konflik dalam keluarga (Duvall \& Miller, 1985). Dalam menghadapi masalah keuangan tersebut, setiap pasangan diharapkan memiliki cara tersendiri yang dapat mengatasi permasalahan mereka dan dapat mengatur kecemasan yang muncul. Cara yang dilakukan oleh setiap pasangan dalam mengatasi situasi sulit dalam pernikahan mereka dapat memengaruhi kesuksesan pernikahan mereka (DeGenova, 2008).

Ketika pasangan tidak dapat mengerti dan menyesuaikan dengan keadaan penyintas, maka akan berakibat pada kondisi penyintas dan keutuhan pernikahan mereka. Hal tersebut dikarenakan berubahnya jumlah pendapatan dan pengeluaran dalam keluarga, pasangan sudah tidak menarik lagi, hubungan intim dan seksual terganggu akibat perubahan fisik yang dialami, terjadinya ketidaksuburan, tidak dapat melaksanakan peran dan kewajiban sebagai istri, serta berubahnya keharmonisan dalam hubungan penyintas dengan pasangannya (Syse \& Kradval, dalam Effendi, 2011). Hal tersebut akan memengaruhi persepsi penyintas kanker serviks mengenai kepuasaan pernikahan mereka.

Hal-hal yang telah dijabarkan di atas seperti perubahan fisik dan dampak secara psikologis penyintas, hubungan intimacy dan seksualitas dengan pasangan, dukungan dari pasangan, situasi krisis seperti masalah dalam kondisi keuangan, dan masalah dalam hal kesetiaan dan kepercayaan merupakan beberapa karakteristik yang dapat memengaruhi kepuasaan 
pernikahan. Kepuasaan pernikahan itu sendiri menurut DeGenova (2008) adalah sejauh mana pasangan merasa puas dan terpenuhi dalam hubungan mereka. Kepuasan pernikahan merupakan konsep yang komprehensif dan menjadi salah satu kriteria dari keberhasilan pernikahan. Kepuasan pernikahan dapat dilihat dengan melihat dua belas karakteristik dalam kepuasan pernikahan. Adapun dua belas karakteristik tersebut adalah communication, admiration and respect, companionship, spiritualy and values, commitment, affection, the ability to deal with crises and stress, responsibility, unselfishness, empathy and sensitivity, honesty, trust, and fidelity, dan adaptability, flexibiliity, and tolerance (DeGenova, 2008).

Dua belas karakteristik yang dikemukakan oleh DeGenova (2008) memiliki pengertian tersendiri yang berkaitan dengan kepuasan pernikahan. Communication adalah kemampuan untuk bertukar ide, fakta, perasaan, sikap, dan kepercayan sehingga pesan dari pengirim dapat secara akurat didengar dan dimaknai oleh penerima. Admiration and respect adalah masingmasing pasangan saling memberikan apresiasi dan menghargai perbedaan individu serta orang lain. Companionship adalah pasangan merasa nyaman satu sama lain, berbagi kepentingan dan aktivitas bersama, dan memiliki banyak tawa bersama. Spirituality and values adalah berbagi aktivitas spiritual bersama serta memiliki nilai yang diwujudkan dengan perilaku religius. Commitment adalah memiliki motivasi yang tinggi untuk membuat pernikahan berhasil dan bersedia menghabisan waktu untuk mewujudkan hal tersebut.

Karakteristik selanjutnya adalah affection yang merupakan kebutuhan masing-masing pasangan untuk cinta dan kasih sayang. The ability to deal with crises and stress adalah mampu mengatasi masalah mereka dan mengatur stres mereka dengan cara yang kreatif. Responsibility adalah pasangan berbagi tanggung jawab secara bersama-sama. Unselfishness adalah tidak bersikap egois dalam pernikahan. Empathy and sensitivity adalah setiap pasangan mau mendengar, mengerti, dan peduli. Honesty, trust, and fidelity adalah setiap pasangan mau untuk menerima kata-kata, percaya, dan menjaga janji bersama-sama. Adaptability, flexibility, and tolerance adalah mau mengakui bahwa orangorang berbeda dalam hal sikap, nilai, kebiasaan, proses berpikir, dan cara melakukan sesuatu.

Teori DeGenova (2008) terkait dua belas karakteristik kepuasan pernikahan dipilih karena karakteristik yang disebutkan dapat dikaitkan dengan konteks penyintas kanker serviks. Contohnya pada karakteristik commitment dan empathy and sensitivity. Pada karakteristik commitment, dari awal didiagnosis hingga pengobatan telah selesai dijalani, penyintas membutuhkan komitmen dari keluarga mereka untuk tetap berada disamping mereka. Hal tersebut dikarenakan mereka sangat membutuhkan dukungan dari keluarga mereka dari awal didiagnosis hingga mereka telah selesai menjalani pengobatan. Selain itu, pada karakteristik empathy and sensitivity, penyintas kanker serviks membutuhkan seseorang yang mau mendengar, mengerti, dan peduli terhadap keadaan mereka.

Penelitian ini bertujuan untuk mendapatkan gambaran kepuasan pernikahan pada penyintas kanker serviks pasca pengobatan kanker. Dengan demikian, dapat diketahui bagaimana penyintas kanker serviks 
mempersepsikan kepuasan pernikahan mereka. Penelitian ini diharapkan dapat memberikan gambaran kepuasan pernikahan yang dilihat dari peran istri yang menjadi penyintas kanker serviks pasca pengobatan kanker. Penelitian ini juga membantu pasangan yang memiliki istri penyintas kanker serviks untuk melihat bagaimana bentuk kepuasan pernikahan pada istri.

\section{METODE PENELITIAN}

Subjek penelitian yang dipilih bergantung pada apa yang ingin diketahui, tujuan dari penelitiannya, apa yang dipertaruhkan, apa yang akan berguna, apa yang akan memiliki kredibilitas, dan apa yang bisa dilakukan dalam waktu dan sumber yang tersedia (Patton, 2002). Penelitian ini melibatkan dua partisipan yang dipilih dengan teknik purposive sampling. Partisipan memiliki kriteria sebagai berikut; (1) Merupakan penyintas kanker serviks dan telah selesai menjalani pengobatan kanker. (2) Status menikah dan tinggal bersama dengan suami.

Jenis penelitian yang digunakan pada penelitian ini adalah penelitian kualitatif. Jenis penelitian ini dipilih karena penelitian kualitatif menekankan pada deskripsi kualitas atau karakteristik dari suatu data (Howitt \& Cramer, 2011). Data yang diperoleh dari penelitian ini dilakukan dengan proses wawancara. Peneliti memilih metode wawancara tersebut karena peneliti bermaksud melakukan eksplorasi terhadap permasalahan yang ada yaitu gambaran kepuasan pernikahan pada penyintas kanker serviks yang telah selesai menjalani pengobatan kanker. Teknik wawancara yang digunakan pada penelitian ini adalah semi terstruktur dengan cara mengajukan open-ended questions.

Teknik analisis data yang dilakukan adalah thematic analysis. Menurut Howitt dan Cramer (2011), thematic analysis adalah metode analisa dari suatu materi berupa teks, termasuk hasil wawancara, untuk mengindikasikan tema utama yang ditemukan dalamnya. Metode ini digunakan karena analisis tematik memungkinkan peneliti untuk menemukan "pola" yang dapat muncul secara acak dalam tumpukan informasi yang tersedia yang kemudian dapat diklasifikasi dengan memberikan label, definisi, atau deskripsi (Boyatzis, dalam Poerwandari, 2013). Analisis tematik dilakukan dengan tahapan yang menjadi familiar dengan data, melakukan koding, mencari tema berdasarkan koding awal, mengecek ulang tema, memberikan definisi dari label pada tema, dan menulis laporan penelitian (Howitt \& Cramer, 2011). Hasil wawancara akan dianalisis dengan memberikan makna pada data, sehingga aspek yang penting akan muncul dalam bentuk koding. Selanjutnya peneliti mengidentifikasi tema yang muncul dari koding yang serupa berdasarkan teori karakteristik kepuasan pernikahan dan memberikan deskripsi pada masingmasing tema.

\section{ANALISIS DAN HASIL}

Berikut ini merupakan gambaran umum partisipan penelitian. Kemudian, akan dipaparkan juga analisis antar individu mengenai kepuasan pernikahan dan faktor-faktor yang mempengaruhi kepuasan pernikahan. 
Tabel 1. Gambaran Umum Partisipan Penelitian

\begin{tabular}{|c|c|c|}
\hline \multicolumn{2}{|c|}{ Partisipan 1} & Partisipan 2 \\
\hline $\begin{array}{l}\text { Nama } \\
\text { Samaran }\end{array}$ & Anah & Yani \\
\hline $\begin{array}{l}\text { Jenis } \\
\text { Kelamin }\end{array}$ & Perempuan & Perempuan \\
\hline Usia & 45 Tahun & 46 Tahun \\
\hline $\begin{array}{l}\text { Suka } \\
\text { Bangsa }\end{array}$ & Sunda & Bali \\
\hline Agama & Islam & Islam \\
\hline $\begin{array}{l}\text { Pendidikan } \\
\text { Terakhir }\end{array}$ & SD & S1 \\
\hline Pekerjaan & $\begin{array}{l}\text { Ibu Rumah } \\
\text { Tangga }\end{array}$ & $\begin{array}{l}\text { Ibu Rumah } \\
\text { Tangga }\end{array}$ \\
\hline $\begin{array}{l}\text { Perkiraan } \\
\text { Sosial } \\
\text { Ekonomi }\end{array}$ & $\begin{array}{l}\text { Menengah } \\
\text { Ke bawah }\end{array}$ & Menengah \\
\hline Suami & $\begin{array}{l}\text { Nanda (52 } \\
\text { Tahun) }\end{array}$ & $\begin{array}{l}\text { Didi } \\
\text { Tahun) }\end{array}$ \\
\hline $\begin{array}{l}\text { Jumlah } \\
\text { Anak }\end{array}$ & 3 & 2 \\
\hline $\begin{array}{l}\text { Lama } \\
\text { Pernikahan }\end{array}$ & 27 Tahun & 20 Tahun \\
\hline $\begin{array}{l}\text { Awal } \\
\text { Diagnosis }\end{array}$ & $\begin{array}{l}\text { Kanker } \\
\text { Serviks } \\
\text { Stadium } \\
\text { 2B }\end{array}$ & $\begin{array}{l}\text { Kanker } \\
\text { Serviks } \\
\text { Stadium } \\
\text { 2B }\end{array}$ \\
\hline $\begin{array}{l}\text { Lama } \\
\text { Menjalani } \\
\text { Pengobatan }\end{array}$ & 1 Tahun & 3 Bulan \\
\hline
\end{tabular}

\section{Analisis Kepuasan Pernikahan Antar Partisipan}

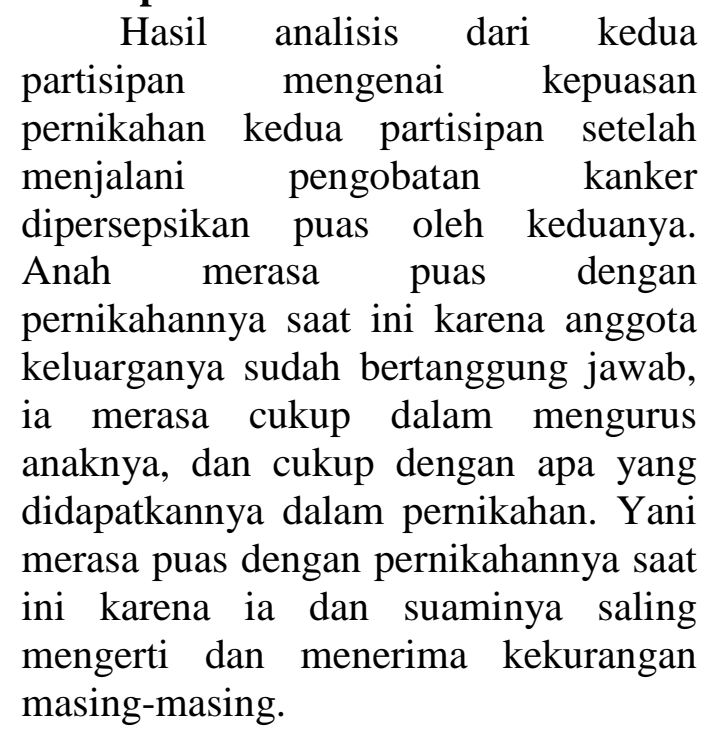

Pada dua belas karakteristik kepuasan pernikahan, terlihat bahwa Anah dan Yani memiliki persamaan persepsi pada karakteristik admiration and respect, companionship, spirituality and values, commitment, affection, responsibility, unselfishness, honesty, trust, and fidelity, serta adaptability, flexibility, and tolerance. Kedua partisipan memiliki perbedaan persepsi pada karakteristik communication, ability to deal with crises and stress, serta empathy and sensitivity. Pada aspek komunikasi, Anah merasa ia dan suaminya cenderung tidak peduli ketika berkomunikasi namun hal tersebut tidak menjadi masalah buat dirinya. Yani merasa suaminya sudah menjadi pendengar yang baik, namun respon yang diberikan oleh suami Yani terhadap apa yang disampaikan Yani terbilang lambat. Yani juga merasa dirinya harus lebih sabar lagi ketika berkomunikasi dengan suaminya.

Pada aspek admiration and respect, Anah sering merasa sakit hati dan tidak dihargai ketika suaminya berkata kasar kepadanya, sedangkan Yani merasa senang karena suaminya sering mengungkapkan perasaannya tentang Yani namun tidak secara langsung. Pada companionship, Anah senang ketika melakukan waktu luang dengan suami, biasanya waktu luang dilakukan dengan menonton televisi di rumah. Yani merasa senang juga ketika melakukan waktu luang bersama keluarga seperti jalan-jalan keluar. Pada spirituality dan values, Anah merasa senang ketika dapat melakukan kegiatan keagamaan dengan suaminya tetapi hal tersebut jarang dilakukan, sedangkan Yani tidak pernah melakukan kegiatan keagamaan bersama suami.

Pada karakteristik commitment, Anah dan Yani sama-sama merasa bahwa keluarga mereka sudah memiliki komitmen. Yani merasa ia dan 
suaminya sudah berkomitmen karena suami dan anggota keluarganya tetap berada di sampingnya hingga saat ini. Yani merasa bahwa mempertahankan pernikahan memang tidak mudah tapi selama ini ia dan suaminya selalu berusaha untuk mempertahankannya karena mempertimbangkan anak mereka juga. Pada affection, Anah maupun Yani merasa senang dengan kasih sayang yang ditunjukkan oleh suami mereka. Anah merasa senang ketika suaminya dapat menunjukkan kasih sayang kepadanya seperti memijit dan membawakan makanan untuk dirinya. Ia juga merasa sudah menunjukkan kasih sayang kepada suaminya. Sedangkan Yani juga merasa senang karena suaminya menunjukkan kasih sayang dengan perhatian kepadanya, begitu pun Yani ke suaminya. Keduanya merasakan perubahan terkait dengan hubungan seksualitas namun keduanya mengalihkan pemikiran mereka tentang hal tersebut ke aktivitas positif lainnya.

Pada ability to deal with crises and stress, Anah dan Yani memiliki cara sendiri untuk menangani permasalahannya. Anah biasanya memiliki masalah seputar anak mereka dan Anah mengaku tidak memikirkan masalahnya terus-menerus tetapi mencoba untuk menyelesaikannya. Yani memiliki masalah terkait dengan perasaan takut bahwa penyakitnya akan muncul kembali. Biasanya ia mengurangi rasa takutnya dengan menonton televisi atau berkegiatan yang membuat ia lupa akan ketakutannya. Pada responsibility, Anah merasa bahwa semua anggota keluarganya sudah menjalankan dan bertanggung jawab dengan peran dan tugasnya dengan baik, bahkan saling membantu tugas anggota keluarga lainnya. Yani merasa bahwa ia dan suaminya sudah melakukan dan bertanggung jawab dengan tugas dan peran mereka.

Pada karakteristik unselfishnes, Anah dan Yani selalu melibatkan semua anggota keluarga ketika berdiskusi mengenai sebuah keputusan yang akan diambil oleh keluarga. Mereka juga tidak merasa ada yang dominan di antara anggota keluarga mereka karena semua anggota keluarga berhak untuk mengambil keputusan. Pada empathy dan sensitivity, Anah dan Yani merasa bahwa mereka berdua dapat menjadi pendengar yang baik untuk pasangan mereka ketika ada masalah. Mereka juga merasa bahwa pasangan mereka telah menjadi pendengar yang baik. Anah mengaku bahwa ia dan suaminya suka memberikan masukan terkait permasalahan yang dihadapi, namun Yani mengaku bahwa suaminya terkadang lambat memberikan respon kepada dirinya. Anah dan Yani mengaku bahwa mereka dapat merasakan jika suami mereka sedang ada masalah.

Pada karakteristik honest, trust, dan fidelity, Yani dan Anah percaya dengan pasangan mereka dan merasa bahwa mereka adalah orang yang dapat dipercaya. Anah dan suaminya tidak pernah membuat janji-janji, sedangkan Yani mengaku bahwa suaminya suka membuat janji dan beberapa kali tidak ditepati. Hal tersebut tidak dipermasalahkan oleh Yani karena ia mengetahui alasan mengapa suaminya tidak menepati janjinya. Pada karakteristik adaptability, flexibility, dan tolerance, Anah dan Yani merasakan adanya perbedaan dalam rutinitas kegiatan seksual mereka dengan suami mereka. Sejauh ini Anah merasa dirinya sudah mampu menyesuaikan dengan perubahan yang terjadi. Yani mengaku ia merasakan perbedaan terkait karakter, hobi dan 
latar belakang keluarga diatasi dengan saling menerima keadaan pasangan.

\section{Analisis Faktor-Faktor Kepuasan Pernikahan Antar Partisipan}

Kedua partisipan memiliki persamaan pada faktor-faktor yang memengaruhi kepuasan pernikahan yaitu kedekatan sebelum pernikahan, tempat tinggal, dan pendapatan keluarga. Pada faktor kedekatan sebelum menikah, Anah dekat dengan suaminya selama satu tahun sedangkan Yani dekat dengan suaminya selama lima tahun. Mereka berdua merasa bahwa waktu pendekatan sebelum menikah tersebut cukup untuk mereka dan pasangannya dapat saling mengenal hingga memutuskan untuk menikah. Pada faktor kepuasan tempat tinggal, Anah merasa kurang puas dan nyaman dengan tempat tinggalnya yang sekarang, sedangkan Yani sudah merasa puas dengan tempat tinggalnya yang sekarang. Anah merasa tempat tinggalnya terbilang kecil sehingga ia tidak leluasa melakukan aktivitas. Pada faktor pendapatan keluarga, keduanya punya pendapatan tetap dari suami mereka. Kebutuhan keluarga mereka juga dapat terpenuhi dengan pendapatan yang keluarga dapatkan, namun untuk keluarga Yani ia menggunakan tabungan juga untuk memenuhi kebutuhan keluarganya.

Faktor yang tidak sama memengaruhi kepuasan pernikahan kedua partisipan adalah kebahagiaan pernikahan orang tua dan pendidikan. Pada faktor kebahagiaan pernikahan orang tua, Anah tidak banyak mengetahui bagaimana pernikahan orang tuanya karena ia telah ditinggal meninggal oleh kedua orang tuanya sejak dia berusia 7 tahun. Anah melihat gambaran kehidupan pernikahan dari kakaknya dan dia mengaku bahwa ada beberapa hal yang diterapannya saat ini dari pernikahan kakaknya. Yani melihat bagaimana pernikahan orang tua dan membuat dirinya sadar bahwa pernikahan memang tidak mudah tetapi pernikahan orang tua yang menginspirasi dan membuat pernikahannya bertahan hingga saat ini. Pada faktor pendidikan, Anah merasa pendidikan tidak berpengaruh terhadap pernikahannya sedangkan Yani merasa hal tersebut berpengaruh. Anah merasa pendidikannya belum membuatnya untuk berpikir lebih jauh dan mengerti tentang pernikahan. Yani merasa pendidikan menunjang perannya sebagai seorang istri dan ibu sehingga ia mampu menghadapi perubahan atau masalah yang terjadi dalam kehidupan rumah tangganya. Pendidikan membuat Yani menjadi setara dengan suaminya dan merasa suami sebagai partner.

\section{DISKUSI}

Anak merupakan salah satu faktor yang memengaruhi kepuasan pernikahan kedua partisipan. Kedua partisipan menyatakan bahwa anak adalah alasan utama mereka mempertahankan hubungan pernikahan mereka. Mereka semangat untuk sembuh karena memikirkan bahwa mereka masih memiliki kewajiban untuk mengurus anak mereka. Selain itu, anak juga merupakan pertimbangan utama dalam mengambil sebuah keputusan dalam keluarga.

Budaya juga merupakan salah satu faktor yang memengaruhi kepuasan pernikahan. Kedua partisipan berasal dari budaya yang berbeda. Pernikahan merupakan asal mula perpaduan dua pola budaya yang dibawa dan diteruskan oleh masing-masing pribadi dan bersumber dari dua keluarga asal mereka (Sadli, dalam Srisusanti \& Zulkaida, 2013). Dion dan Dion (dalam Ardhani, 2015) menyatakan bahwa budaya memengaruhi individu dan 
kelompok dalam memandang dan mengkonsepkan cinta dan keintiman relasi. Berdasarkan hasil penelitian ini, budaya tidak memengaruhi kedua partisipan dalam mempersepsikan kepuasan pernikahan. Faktor budaya dan latar belakang keluarga kedua partisipan memengaruhi bagaimana mereka berkomunikasi, menunjukkan cinta dan kasih sayang, serta memilih cara untuk memecahkan masalah mereka. Kepuasan pernikahan yang dulu memengaruhi kepuasan penikahan penyintas saat ini. Peneliti menfokuskan penelitian pada kepuasaan pernikahan penyintas saat ini, namun pada pelaksanaannya kepuasan pernikahan penyintas pada saat ini dipengaruhi oleh pengalamannya yang dulu. Salah satu partisipan pernah merasa dikhianati oleh pasangannya, hal tersebut masih diingat oleh partisipan walaupun ia mengaku saat ini sudah berusaha untuk melupakannya. Ketika kedua partisipan didiagnosis kanker serviks hal tersebut merupakan salah satu penyebab stres yang berasal dari luar. Kedua partisipan berusaha menyesuaikan diri mereka dari kerjadian tersebut karena kepuasan pernikahan yang dirasakan suami istri berkaitan erat dengan keberhasilan penyesuaian yang dilakukan oleh masing-masing pihak. Masing-masing pasangan harus ada penyesuaian diri, baik dengan kehidupan baru yang akan dijalani, masalah baru, kebutuhan baru, dan harus mampu mengatasi masalah yang muncul.

Kepuasan pernikahan dipengaruhi oleh kepribadian yang sesuai di mana pasangan memiliki kecocokan dan saling memahami satu sama lain (Skolnick dalam Lemme, 1995). Hal yang penting juga yaitu setiap pasangan saling melengkapi satu sama lain dengan kelebihan yang satu dapat menutupi kekurangan yang lainnya. Setiap individu mempunyai perbedaan dan keunikan masing-masing (Goode, dalam Srisusanti \& Zulkaida, 2013). Kedua partisipan merasakan adanya perbedaan kepribadian antara mereka dengan suami mereka. Perbedaan tersebut terkadang mengganggu hubungan mereka dengan pasangan mereka, namun mereka selalu berusaha menerima perbedaan tersebut hingga dapat mempertahankan pernikahan mereka sampai saat ini.

Pengobatan yang dijalani kedua partisipan menimbulkan dampak yang sama walaupun kedua partisipan melakukan rangkaian pengobatan yang berbeda. Partisipan pertama menjalani pengobatan berupa kemoterapi dan radiasi, sedangkan partisipan kedua menjalani pengobatan kemoterapi dan pembedahan. Pengobatan tersebut menimbulkan dampak yang sama pada keluhan fisik seperti gangguan pada organ seksual dan kelelahan pada kedua partisipan. Selain keluhan fisik, partisipan juga mengungkapkan dampak psikologis setelah menjalani pengobatan berupa cemas akan kambuhnya penyakit mereka. Respon psikologis berupa ketakutan terhadap kekambuhan penyakit atau metastasis penyakit merupakan respon perempuan yang telah menjalani kanker serviks (Hobbs; McCorkle, et al., dalam Erfina, Afiyanti, \& Rachmawati, 2010). Perubahan sosial yang terjadi setelah melakukan pengobatan adalah perubahan pada gambaran diri dan merasa harga diri rendah karena malu berhubungan dengan orang lain di sekitarnyan (Otto, dalam Erfina, Afiyanti, \& Rachmawati, 2010). Terkait perubahan sosial, hal tersebut berbeda dengan yang diungkapkan partisipan. Setelah menjalani pengobatan, mereka masih berinteraksi baik pada suami, keluarga, dan rekan mereka.

Kedua partisipan merasakan perubahan dalam hal seksualitas dan 
intimacy mereka dengan pasangan mereka. Evelyn (2005) mengungkapkan bahwa penyintas kanker serviks, khususnya yang telah menjalani pengobatan seperti kemoterapi, radiasi, dan pembedahan akan memiliki risiko untuk mengalami masalah seksualitas. Menopause dini membuat penyintas mengalami penurunan hormon yang menyebabkan secara psikologis kurang bergairah untuk melakukan hubungan seksual. Hal tersebut dirasakan oleh kedua partisipan yang mulai tidak bergairah ketika suami mereka mengajak berhubungan seksual. Penyintas kanker serviks merasa takut ketika suaminya mulai mendekatinya dan mengajak berhubungan seksual dan juga merasa sakit pada vaginanya. Hal tersebut dirasakan oleh salah satu partisipan yang masih merasa takut ketika suaminya mulai mendekatinya. Perubahan dalam kegiatan seksual tersebut membuat partisipan dan suaminya mengalihkan kegiatan seksual pada kegiatan bersama lainnya.

Kesetiaan dan kepercayaan terhadap pasangan tidak dirasakan bermasalah pada pernikahan mereka. Kedua partisipan dapat mempertahankan hubungan mereka dan pasangannya hingga saat ini. Keduanya juga selalu berusaha untuk menerima perbedaan dan perubahan yang terjadi antara mereka dan pasangan mereka. Terkait dengan kepercayaan dengan pasangan, kedua partisipan percaya dengan pasangan mereka dan merasa bahwa mereka adalah orang yang dapat dipercaya. Hal tersebut dikarenakan suami dari kedua partisipan akan menepati janji yang telah mereka buat. Ketika janji yang telah dibuat tidak ditepati, biasanya partisipian telah mengetahui alasannya dan tidak mempermasalahkan hal tersebut.

Dukungan sosial yang didapatkan oleh kedua partisipan dirasakan berkurang dari sebelum mereka selesai menjalani pengobatan. Setelah menjalani pengobatan, biasanya penyintas merasa bahwa dukungan yang ia terima dari keluarga dan temantemannya mulai berkurang dari saat ia masih menjalani pengobatan (Baider, Cooper, \& De-Nour, 2000). Dukungan yang mulai berkurang tersebut membuat kedua partisipan terlibat aktif pada yayasan kanker. Keduanya merasakan manfaat setelah terlibat aktif dalam yayasan kanker karena mereka mendapatkan teman, dukungan, dan informasi terkait dengan penyakit mereka. Keterlibatan mereka juga membuat mereka lebih kuat dalam menghadapi hidup karena bertemu dengan orang-orang yang memiliki pengalaman yang sama dengan mereka.

Perubahan ekonomi keluarga setelah pengobatan sudah tidak dirasakan lagi oleh kedua partisipan. Para penyintas kanker sangat mengkhawatirkan sakitnya, ditambah dengan mengeluarkan biaya yang besar sehingga sering muncul kecemasan antara memikirkan sakit atau biaya yang harus dikeluarkan (Yolanda \& Karwur, 2013). Permasalahan keuangan tersebut tidak hanya dirasakan oleh penyintas kanker saja, tetapi oleh pasangannya juga. Perubahan tersebut lebih mereka rasakan ketika mereka sedang menjalani pengobatan karena pada saat itu mereka membutuhkan biaya yang besar. Kedua partisipan menggunakan cara yang berbeda untuk pengobatan, salah satu partisipan menggunakan bantuan dari pemerintah sedangkan partisipan lain menggunakan uang pribadi dengan menjual harta benda mereka. Ketika mereka selesai menjalani pengobatan, mereka mengaku keuangan dalam keluarga berangsur pulih.

Pada karateristik ability to deal with crises and stress, kedua partisipan memiliki cara yang berbeda dalam 
mengatasi permasalahan mereka. Duvall dan Miller (1985) menyebutkan ada tiga cara penyelesaian konflik dalam perkawinan, yaitu: pasangan berdebat atau berargumentasi secara terbuka dengan melepaskan emosi dan lebih terfokus pada pokok permasalahan yang terjadi dibanding terfokus pada pasangan, pasangan saling menghindari untuk membicarakan permasalahan, pendekatan ini tetap menampilkan adanya perbedaan pendapat dalam tingkat yang minimal tetapi mereka mencoba menghilangkan situasi konflik, dan pasangan menyelesaikan konflik ke arah rekonsiliasi. Satu partisipan ketika memiliki masalah dengan pasangan biasanya ia berdiskusi dengan pasangannya, namun ia seringkali tidak dapat menahan amarahnya hingga dapat membanting barang di rumah ketika marah. Sedangkan partisipan lain ketika ada masalah bisa mengatur rasa takut dan khawatirnya dengan cara-cara seperti menonton televisi atau membaca AlQuran. Perbedaan cara penyelesaikan konfliknya berbeda namun tujuan mereka tetap sama agar mereka merasa lebih tenang dan tidak memikirkan masalah tersebut kembali.

Menurut DeGenova (2008), spirituality and values memiliki kontribusi pada kepuasan pernikahan. Pasangan yang berhasil akan berbagi aktivitas spiritual, pasangan memiliki tingkat religious orientation yang tinggi dan kepercayaan yang sama, serta nilai yang diwujudkan dengan perilaku religius. Hal tersebut tidak sesuai dengan persepsi kedua partisipan terkait dengan aktivitas keagamaan antara mereka dan pasangannya. Kedua partisipan tidak melakukan kegiatan keagamaan yang rutin bersama pasangannya, namun kedua partisipan tidak mempermasalahkan hal tersebut.
Menurut mereka, kegiatan keagamaan adalah urusan pribadi setiap individu.

\section{SIMPULAN}

Berdasarkan hasil analisis yang telah dilakukan untuk setiap partisipan penelitian dan hasil analisis gabungan di antara kedua partisipan tersebut, dapat ditarik beberapa kesimpulan yang dapat menjawab masalah penelitian ini.

1. Kehidupan pernikahan kedua partisipan setelah menjalani pengobatan kanker dipersepsikan puas oleh keduanya. Hal tersebut dikarenakan partisipan merasa cukup dengan apa yang didapatkannya dalam pernikahan dan mencoba untuk saling mengerti serta menerima kekurangan masingmasing pasangan.

2. Terdapat karakteristik yang sama dalam mendukung dan tidak mendukung kepuasan pernikahan kedua partisipan. Karakteristik yang mendukung kepuasan pernikahan kedua partisipan yaitu companionship, commitment, responsibility, unselfishness, honesty, trust, and fidelity, serta adaptability, flexibility, and tolerance. Karakteristik yang tidak mendukung kepuasan pernikahan kedua partisipan yaitu admiration and respect, spirituality and values, serta affection.

3. Terdapat karakteristik yang berbeda dalam memengaruhi kepuasan pernikahan kedua partisipan yaitu communication, ability to deal with crises and stress, serta empathy and sensitivity. Perbedaan tersebut terkait dengan perbedaan penghayatan dan pengaruhnya terhadap kepuasan pernikahan kedua partisipan.

4. Kedua partisipan memiliki persamaan pada faktor-faktor yang memengaruhi kepuasan pernikahan yaitu kedekatan sebelum pernikahan, 
tempat tinggal, dan pendapatan keluarga. Faktor yang memiliki pengaruh berbeda terhadap kepuasan pernikahan kedua partisipan adalah kebahagiaan pernikahan orang tua dan pendidikan.

5. Suami memiliki pengaruh yang besar dalam memberikan persepsi kepuasan pernikahan bagi peyintas kanker serviks. Hal tersebut dikarenakan persepsi terhadap kepuasan pernikahan mereka tidak hanya dipengaruhi oleh pandangan mereka terhadap pernikahan mereka tetapi bagaimana mereka memandang persepsi suami mereka terhadap pernikahan mereka.

\section{SARAN}

Hasil peneltian ini memunculkan beberapa saran metodologis yang dapat menjadi pertimbangan untuk peneliti selanjutnya yang akan meneliti tentang gambaran kepuasan pernikahan pada penyintas kanker serviks pasca pengobatan kanker. Pada penelitian berikutnya diharapkan untuk melihat kepuasan pernikahan dari sisi suami penyintas juga karena masalah yang dihadapi penyintas juga dirasakan oleh pasangan mereka. Selain itu, suami juga memiliki peranan penting dalam membentuk persepsi istri terkait kepuasan pernikahan mereka. Selain itu, pada panelitian selanjutnya diharapkan peneliti melakukan kontak dengan yayasan kanker atau komunitas penyintas kanker beberapa bulan sebelum pengambilan data. Topik penelitian ini dapat dikatakan sebagai topik yang sensitif sehingga perlunya membangun raport yang baik sebelum melakukan ambil data dan memastikan bahwa partisipan bersedia bercerita mengenai hubungan pernikahannya.

Hasil analisis data penelitian juga menghasilkan beberapa saran praktis. Melalui penelitian ini diharapkan dapat memberikan gambaran mengenai kepuasan pernikahan pada penyintas kanker serviks setelah selesai pengobatan. Keluarga, terutama suami, diharapkan dapat memberikan dukungan, kasih sayang, dan perhatian kepada penyintas tidak hanya saat penyintas sedang menjalani pengobatan tetapi saat penyintas telah selesai menjalani pengobatan. Selanjutnya, hasil penelitian ini diharapkan dapat memberikan informasi kepada penyintas kanker serviks mengenai gambaran kepuasan pernikahan penyintas kanker serviks setelah menjalani pengobatan. Informasi terkait gambaran kepuasan pernikahan dapat dibuat dalam bentuk poster yang dimuat pada majalah dinding di yayasan kanker. Setelah mengetahui gambaran kepuasan pernikahan, diharapkan penyintas lebih menyadari pentingnya kepuasan pernikahan karena berhubungan dengan kualitas hidup penyintas. Selain itu, hasil dari penelitian ini menunjukkan bahwa pentingnya peran suami dalam memengaruhi persepsi istri terkait dengan pernikahan penyintas kanker serviks. Terkait hal tersebut diharapkan institusi terkait seperti yayasan kanker mengadakan seminar terkait dengan bagaimana cara yang seharusnya dapat dilakukan suami ketika menghadapi istri mereka yang merupakan seorang penyintas kanker serviks. Seminar tersebut diharapkan dapat menambah pengetahuan suami dalam memberikan dukungan dan kasih sayang kepada istri mereka yang merupakan seorang penyintas kanker serviks.

\section{DAFTAR PUSTAKA}

Afiyanti, Y., Azwar, A., Setyowati, \& Andrijono. (2014). Women's experiences of sexual problems after cervical cancer treatment: lessons from 
Indonesian women. Makara J. Health Res., 18(2)

Baider, L., Cooper, C. L., \& De-Nour, A. K. (2000). Cancer and the family $\left(2^{\text {nd }}\right.$ ed.). USA: Wiley.

DeGenova, M. K. (2008). Intimate relationship, marriages, \& families (7th ed.). New York: McGraw-Hill, Inc.

Diananda, R. (2008). Mengenal seluk beluk kanker. Yogyakarta: Kata hati.

Duvall, E. M., \& Miller, B. C. (1985). Marriage and family development (6th ed.). New York: McMiller Company.

Effendi, D. P. (2011). Studi fenomenologi: pengalaman seksualitas perempuan pasca terapi kanker servik. Tesis Fakultas Ilmu Keperawatan. Universitas Indonesia, Depok.

Erfina., Afiyanti, Y., \& Rachmawati, I. N. (2010). Pengalaman perempuan setelah menjalani terapi kanker serviks. Jurnal Keperawatan Indonesia. Vol. 13 No.3.

Evelyn, H. L. (2005). Sexuality issue of women with cancer. Society of gynaecologyc nurse oncology. Vol. 15 No. 3.

Fitriana, N. A. \& Ambarini, T. K. (2012). Kualitas hidup pada penderita kanker serviks yang menjalani pengobatan radioterapi. Jurnal Psikologi Klinis dan Kesehatan Mental. Vol. 1No. 02.

Gamel, C., Hengeveld, M., \& Davis, B. (2000). Informational needs about the effects of gynaecological cancer on sexuality: review of the literature. Journal of clinical nursing, 9:678-688.

Hewitt, M., Herdman, R., \& Holland, J. (2004). Meeting psychosocial needs of women with breast cancer.
Washington DC: The National Academies Press.

Hidayat, E. (2005). Hubungan antara kepuasan perkawinan dan kualitas hidup pada survivors kanker payudara extended stage middle-adulthood. Skripsi Fakultas Psikologi. Universitas Katolik Indonesia Atma Jaya, Jakarta.

Howit, D. \& Cramer, D. (2011). Introduction to Research methods in Psychology (3rd ed.). Harlow: Pearson Education Limited.

Keyser, K., \& Scot. (2007). Helping couples cope with women's cancers: an evidence based approach for practitioners. USA: Springer.

Nurrachman, N., Shanti, T.I., Pandia, W.S., Suci, E.S., Hidajat, L.L., Sukmaningrum, E., Partasari, W.D., Warmiyati, M.M., Wibawa, D.S. (2011). Psikologi perempuan: pendekatan kontekstual Indonesia. Jakarta: Universitas Atma Jaya.

Patton, M. Q. (2002). Qualitative evaluation and research methods (3rd ed.). London: Sage Publications, Inc.

Poerwandari, E. K. (2013). Pendekatan kualitatif untuk penelitian perilaku manusia. Lembaga Pengembangan Sarana Pengukuran dan Pendidikan Psikologi (LPSP3). Jakarta: Fakultas Psikologi Universitas Indonesia

Sukardja, I. D. E. (2000). Onkologi klinik edisi 2. Surabaya: Airlangga University Press

Yolanda, A. E., \& Karwur, F. F. (2008). Tingkat kecemasan pasien kanker serviks pada golongan ekonomi rendah yang mengikuti program kemoterapi di RSUD Dr. Moewardi. Sains Medika, Vol.5

No. 2 